\title{
The sensitivity of stratospheric ozone changes through the 21st century to $\mathrm{N}_{2} \mathrm{O}$ and $\mathrm{CH}_{4}$
}

\author{
L. E. Revell ${ }^{1,2,3}$, G. E. Bodeker ${ }^{3}$, P. E. Huck ${ }^{3}$, B. E. Williamson ${ }^{2}$, and E. Rozanov ${ }^{4,5}$ \\ ${ }^{1}$ National Institute of Water and Atmospheric Research, Christchurch, New Zealand \\ ${ }^{2}$ Department of Chemistry, University of Canterbury, New Zealand \\ ${ }^{3}$ Bodeker Scientific, Alexandra, New Zealand \\ ${ }^{4}$ Physical-Meteorological Observatory Davos/World Radiation Center, Davos, Switzerland \\ ${ }^{5}$ Institute for Atmospheric and Climate Science ETH, Zurich, Switzerland
}

Correspondence to: L. E. Revell (laura@bodekerscientific.com)

Received: 11 June 2012 - Published in Atmos. Chem. Phys. Discuss.: 18 July 2012

Revised: 27 November 2012 - Accepted: 28 November 2012 - Published: 3 December 2012

\begin{abstract}
Through the 21st century, anthropogenic emissions of the greenhouse gases $\mathrm{N}_{2} \mathrm{O}$ and $\mathrm{CH}_{4}$ are projected to increase, thus increasing their atmospheric concentrations. Consequently, reactive nitrogen species produced from $\mathrm{N}_{2} \mathrm{O}$ and reactive hydrogen species produced from $\mathrm{CH}_{4}$ are expected to play an increasingly important role in determining stratospheric ozone concentrations. Eight chemistry-climate model simulations were performed to assess the sensitivity of stratospheric ozone to different emissions scenarios for $\mathrm{N}_{2} \mathrm{O}$ and $\mathrm{CH}_{4}$. Global-mean total column ozone increases through the 21st century in all eight simulations as a result of $\mathrm{CO}_{2}$-induced stratospheric cooling and decreasing stratospheric halogen concentrations. Larger $\mathrm{N}_{2} \mathrm{O}$ concentrations were associated with smaller ozone increases, due to reactive nitrogen-mediated ozone destruction. In the simulation with the largest $\mathrm{N}_{2} \mathrm{O}$ increase, global-mean total column ozone increased by $4.3 \mathrm{DU}$ through the 21 st century, compared with 10.0 DU in the simulation with the smallest $\mathrm{N}_{2} \mathrm{O}$ increase. In contrast, larger $\mathrm{CH}_{4}$ concentrations were associated with larger ozone increases; global-mean total column ozone increased by $16.7 \mathrm{DU}$ through the 21 st century in the simulation with the largest $\mathrm{CH}_{4}$ concentrations and by $4.4 \mathrm{DU}$ in the simulation with the lowest $\mathrm{CH}_{4}$ concentrations. $\mathrm{CH}_{4}$ leads to ozone loss in the upper and lower stratosphere by increasing the rate of reactive hydrogen-mediated ozone loss cycles, however in the lower stratosphere and troposphere, $\mathrm{CH}_{4}$ leads to ozone increases due to photochemical smogtype chemistry. In addition to this mechanism, total column ozone increases due to $\mathrm{H}_{2} \mathrm{O}$-induced cooling of the strato-
\end{abstract}

sphere, and slowing of the chlorine-catalyzed ozone loss cycles due to an increased rate of the $\mathrm{CH}_{4}+\mathrm{Cl}$ reaction. Stratospheric column ozone through the 21 st century exhibits a near-linear response to changes in $\mathrm{N}_{2} \mathrm{O}$ and $\mathrm{CH}_{4}$ surface concentrations, which provides a simple parameterization for the ozone response to changes in these gases.

\section{Introduction}

Through the 21st century, decreasing concentrations of stratospheric chlorine and bromine, together with increasing concentrations of $\mathrm{CO}_{2}$, are projected to lead to increased global-mean stratospheric ozone (Eyring et al., 2010). $\mathrm{CO}_{2}$, the dominant anthropogenic greenhouse gas (GHG), elevates ozone by cooling the stratosphere, which slows the gas-phase ozone loss cycles (e.g. World Meteorological Organization, 1998; Rosenfield et al., 2002; IPCC/TEAP, 2005). Of the GHGs controlled under the Kyoto Protocol, those with the highest radiative forcing after $\mathrm{CO}_{2}$ are $\mathrm{N}_{2} \mathrm{O}$ and $\mathrm{CH}_{4}$, both of which lead to changes in ozone via chemical processes. Although the roles of $\mathrm{N}_{2} \mathrm{O}$ and $\mathrm{CH}_{4}$ in ozone chemistry are qualitatively understood, the sensitivity of ozone to these gases has not been thoroughly investigated. It is the aim of this work to gain a quantitative understanding of the sensitivity of stratospheric ozone to $\mathrm{N}_{2} \mathrm{O}$ and $\mathrm{CH}_{4}$ through the use of a coupled chemistry-climate model. 
$\mathrm{N}_{2} \mathrm{O}$ in the stratosphere affects ozone predominantly through $\mathrm{NO}_{\mathrm{x}}$-catalyzed $\left(\mathrm{NO}_{\mathrm{x}}=\mathrm{NO}+\mathrm{NO}_{2}\right)$ ozone-loss cycles (Crutzen, 1970). However, increases in $\mathrm{N}_{2} \mathrm{O}$ do not necessarily lead to increases in $\mathrm{NO}_{\mathrm{x}}$ due changes in the chemical, dynamical and radiative environment of the stratosphere, as discussed in detail by Revell et al. (2012). For example, the sink for $\mathrm{NO}_{\mathrm{x}}$ is temperature dependent, so $\mathrm{CO}_{2}$ induced cooling of the stratosphere decreases $\mathrm{NO}_{\mathrm{x}}$ abundances by slowing the highly temperature-dependent Reaction (R1) (below). The subsequent increase in $\mathrm{N}$ leads to an increase in the rate of Reaction (R2), therefore decreasing $\mathrm{NO}_{\mathrm{x}}$ abundances (Rosenfield and Douglass, 1998).

$\mathrm{N}+\mathrm{O}_{2} \rightarrow \mathrm{NO}+\mathrm{O}$

$\mathrm{N}+\mathrm{NO} \rightarrow \mathrm{N}_{2}+\mathrm{O}$

More recently, Plummer et al. (2010) found that nitrogen species induced large stratospheric ozone losses once the effects of $\mathrm{CO}_{2}$-induced stratospheric cooling were removed. In addition, increasing sea-surface temperatures (SSTs) are projected to strengthen the Brewer-Dobson circulation, resulting in a faster removal rate of reservoir nitrogen species from the stratosphere (Cook and Roscoe, 2012). As a consequence, $\mathrm{NO}_{\mathrm{x}}$ abundances will be reduced.

$\mathrm{CH}_{4}$ weakens the ozone-depleting effectiveness of $\mathrm{N}_{2} \mathrm{O}$ by producing reactive hydrogen species which: (1) slow $\mathrm{NO}_{\mathrm{x}}-$ catalyzed ozone loss cycles in the upper stratosphere (Revell et al., 2012), and (2) remove $\mathrm{NO}_{\mathrm{x}}$ from the middle stratosphere through reactions to form $\mathrm{HNO}_{3}$ (Randeniya et al., 2002). Similarly, chlorine radicals produced by photolysis of ozone-depleting substances (ODSs), such as the CFCs, react with $\mathrm{NO}_{\mathrm{x}}$ to form $\mathrm{ClONO}_{2}$, thus reducing $\mathrm{NO}_{\mathrm{x}}$ abundances (Ravishankara et al., 2009). However, as the chlorine loading of the stratosphere decreases through the 21st century (owing to the success of the Montreal Protocol for Substances that Deplete the Ozone Layer and later amendments and adjustments), the effect of chlorine on $\mathrm{NO}_{\mathrm{x}}$ will become less important. Furthermore, Ravishankara et al. (2009) have shown that $\mathrm{N}_{2} \mathrm{O}$ is the dominant ODS currently emitted, and is expected to remain so through the remainder of the $21 \mathrm{st}$ century.

The oxidation of $\mathrm{CH}_{4}$ produces $\mathrm{HO}_{\mathrm{x}}$ radicals (here: $\mathrm{HO}_{\mathrm{x}}=\mathrm{H}+\mathrm{OH}+\mathrm{HO}_{2}$ ) which catalyze ozone destruction cycles. In the upper stratosphere, the dominant $\mathrm{HO}_{\mathrm{x}}-$ catalyzed ozone loss cycle is Cycle I (rate-determining step in bold):

$\mathrm{OH}+\mathrm{O}_{3} \rightarrow \mathrm{HO}_{2}+\mathrm{O}_{2}$

$\underline{\mathrm{HO}_{2}+\mathrm{O} \rightarrow \mathrm{OH}+\mathrm{O}_{2}}$

$\mathrm{O}+\mathrm{O}_{3} \rightarrow 2 \mathrm{O}_{2}$

In the lower stratosphere, where the ratio of $\mathrm{O}_{3}$ to $\mathrm{O}$ is much larger compared with in the upper stratosphere, the dominant
$\mathrm{HO}_{\mathrm{x}}$-catalyzed ozone loss cycle is Cycle II, which involves the reaction of $\mathrm{HO}_{2}$ with $\mathrm{O}_{3}$ in the rate-determining step:

$\mathrm{HO}_{2}+\mathrm{O}_{3} \rightarrow \mathrm{OH}+2 \mathrm{O}_{2}$

$\underline{\mathrm{OH}+\mathrm{O}_{3} \rightarrow \mathrm{HO}_{2}+\mathrm{O}_{2}}$

$2 \mathrm{O}_{3} \rightarrow 3 \mathrm{O}_{2}$

$\mathrm{HO}_{2}$ can also react with $\mathrm{NO}$, leading to ozone production via Cycle III (so-called "photochemical smog chemistry") (Johnston and Podolske, 1978; Nevison et al., 1999; Portmann and Solomon, 2007; Fleming et al., 2011). Cycle III occurs predominantly in the troposphere and very lower stratosphere, where the concentration of $\mathrm{CO}$ is sufficiently large.

$\mathrm{OH}+\mathrm{CO}+\mathrm{O}_{2} \rightarrow \mathrm{HO}_{2}+\mathrm{CO}_{2}$

$\mathrm{HO}_{2}+\mathrm{NO} \rightarrow \mathrm{OH}+\mathrm{NO}_{2}$

$\mathrm{NO}_{2}+h v \rightarrow \mathrm{NO}+\mathrm{O}$

$\mathrm{O}+\mathrm{O}_{2}+\mathrm{M} \rightarrow \mathrm{O}_{3}+\mathrm{M}$

$\mathrm{CO}+2 \mathrm{O}_{2} \rightarrow \mathrm{CO}_{2}+\mathrm{O}_{3}$

Portmann and Solomon (2007) and Fleming et al. (2011) have shown that the predominant effect of increasing $\mathrm{CH}_{4}$ is to increase total column ozone. This occurs via Cycle III in the lower atmosphere, and via $\mathrm{H}_{2} \mathrm{O}$-induced stratospheric cooling in the middle stratosphere, which slows the temperature-dependent gas-phase ozone loss cycles. Additionally, increasing $\mathrm{CH}_{4}$ increases the reaction rate of Reaction (R3) (see below), which increases the rate of conversion of chlorine to the $\mathrm{HCl}$ reservoir and thereby slows the chlorine-catalyzed ozone loss cycles throughout the stratosphere. The removal of reactive chlorine by Reaction (R3) is less effective in polar regions where reaction with $\mathrm{HCl}$ is not important for chlorine deactivation (Douglass et al., 1995).

$\mathrm{CH}_{4}+\mathrm{Cl} \rightarrow \mathrm{CH}_{3}+\mathrm{HCl}$

Oman et al. (2010) studied the effects of reactive nitrogen and hydrogen species on stratospheric ozone using two chemistry-climate model (CCM) simulations constrained by the IPCC SRES A1B and A2 emissions scenarios for GHGs, which portray intermediate (A1B) and large (A2) increases in $\mathrm{CO}_{2}, \mathrm{~N}_{2} \mathrm{O}$ and $\mathrm{CH}_{4}$ (Nakicenovic and Swart, 2000). The evolution of upper stratospheric ozone in the two CCM simulations was similar, because although $\mathrm{NO}_{\mathrm{x}}$ and $\mathrm{HO}_{\mathrm{x}}$ species led to larger ozone losses in A2 compared with A1B, they were compensated by the effects of larger increases in $\mathrm{CO}_{2}-$ induced stratospheric cooling.

Here an analysis of the chemical sensitivity of stratospheric ozone to $\mathrm{N}_{2} \mathrm{O}$ and $\mathrm{CH}_{4}$ through the 21st century is presented using the results from eight $\mathrm{CCM}$ simulations. Four simulations differed only in their $\mathrm{N}_{2} \mathrm{O}$ concentrations, while the other four differed in their $\mathrm{CH}_{4}$ concentrations. The same concentration scenario for $\mathrm{CO}_{2}$ was used across all eight simulations. 
Table 1. Summary of scenarios for the CCM simulations ${ }^{\mathrm{a}}$.

\begin{tabular}{lllr}
\hline Simulation & $\mathrm{N}_{2} \mathrm{O}$ scenario & $\mathrm{CH}_{4}$ scenario & $\Delta \mathrm{O}_{3}(\mathrm{DU})^{\mathrm{b}}$ \\
\hline $\mathrm{N}_{2} \mathrm{O}-2.6$ & RCP 2.6 & SRES A1B & 10.0 \\
$\mathrm{~N}_{2} \mathrm{O}-4.5$ & RCP 4.5 & SRES A1B & 7.6 \\
$\mathrm{~N}_{2} \mathrm{O}-6.0$ & RCP 6.0 & SRES A1B & 4.9 \\
$\mathrm{~N}_{2} \mathrm{O}-8.5$ & RCP 8.5 & SRES A1B & 4.3 \\
$\mathrm{CH}_{4}-2.6$ & SRES A1B & RCP 2.6 & 4.4 \\
$\mathrm{CH}_{4}-4.5$ & SRES A1B & RCP 4.5 & 5.2 \\
$\mathrm{CH}_{4}-6.0$ & SRES A1B & RCP 6.0 & 9.1 \\
$\mathrm{CH}_{4}-8.5$ & SRES A1B & RCP 8.5 & 16.7 \\
\hline
\end{tabular}

a All simulations used the IPCC SRES A1B scenario for $\mathrm{CO}_{2}$ and adjusted $\mathrm{A} 1$ scenario for halocarbons.

${ }^{\mathrm{b}}$ Change in global-mean total column ozone through the 21st century (2090s decade minus the decade from 2015-2024), expressed in Dobson units.

\section{Computational methods}

\subsection{The NIWA-SOCOL chemistry-climate model}

The evolution of stratospheric ozone was simulated using the NIWA-SOCOL (National Institute of Water and Atmospheric Research - SOlar Climate Ozone Links) CCM (SPARC CCMVal, 2010). NIWA-SOCOL is based on SOCOL v2.0 (Schraner et al., 2008), which consists of the MAECHAM4 global climate model (Manzini et al., 1997) coupled to a modified version of the MEZON chemistry transport model (Egorova et al., 2003). NIWA-SOCOL includes 41 chemical species, 140 gas-phase reactions, 46 photolysis reactions and 16 heterogeneous reactions. Chemical constituents are advected by a hybrid transport scheme (Zubov et al., 1999), and the chemical solver algorithm uses a Newton-Raphson iterative method. A 15-min time step is used for dynamical processes, while radiative and chemical calculations are performed every two hours. CCM simulations were performed for the period 2005-2100, with the first ten years discarded as spin-up.

The NIWA-SOCOL model attributes ozone loss to 15 catalytic cycles (listed by Revell et al., 2012), using a diagnostic approach similar to that employed by Lee et al. (2002). Odd-oxygen $\left(\mathrm{O}+\mathrm{O}\left({ }^{1} \mathrm{D}\right)+\mathrm{O}_{3}\right)$ removal rates (molecules $\mathrm{cm}^{-3} \mathrm{~s}^{-1}$ ) are calculated within the model based on the rate-limiting steps of the corresponding reaction cycles, recorded and accumulated as daily means in each model grid cell.

\subsection{Concentrations scenarios}

Eight GHG concentration scenarios were constructed, as described in Table 1, using combinations of the IPCC SRES A1B concentrations scenario for GHGs (Nakicenovic and Swart, 2000), and the four Representative Concentration Pathways (RCPs) 2.6, 4.5, 6.0 and 8.5, named according to the radiative forcings (in $\mathrm{W} \mathrm{m}^{-2}$ ) reached by 2100 . The RCPs were developed for the climate modelling community

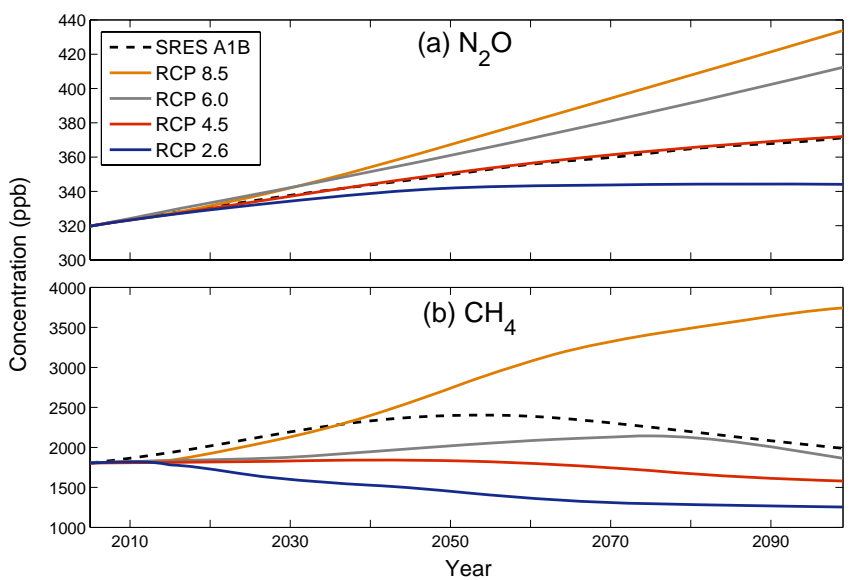

Fig. 1. (a) $\mathrm{N}_{2} \mathrm{O}$ and (b) $\mathrm{CH}_{4}$ surface concentrations used in the CCM simulations.

to provide possible concentration trajectories for the main climate change forcing agents. They do not include socioeconomic, emission and climate projections (van Vuuren et al., 2011). Surface concentrations of $\mathrm{N}_{2} \mathrm{O}$ and $\mathrm{CH}_{4}$ for the individual scenarios are shown in Fig. 1. All simulations used the SRES A1B scenario for $\mathrm{CO}_{2}$ and the adjusted A1 scenario for halocarbons (Daniel et al., 2007).

Sea-surface temperatures were prescribed under the SRES A1B scenario using output from the ECHAM5/MPIOM atmosphere-ocean general circulation model (AOGCM). To test whether they would have been different if they had been calculated from AOGCM simulations using the constructed GHG concentration scenarios (Table 1), SSTs for each of the eight scenarios were simulated using the simple climate model MAGICC6, which is designed to emulate AOGCMs (Meinshausen et al., 2011). Globally averaged annual-mean SSTs under the SRES A1B and the eight GHG concentrations scenarios are displayed in Fig. 2. SSTs exhibit a greater spread by 2100 in simulations employing different $\mathrm{CH}_{4}$ scenarios, owing to the greater radiative forcing of $\mathrm{CH}_{4}$ compared with $\mathrm{N}_{2} \mathrm{O}$. However, results do not significantly differ from the A1B simulation (at most, there is a difference of $0.5 \mathrm{~K}$ between the $\mathrm{CH}_{4}-8.5$ - and A1B-based SSTs in 2100). The conclusions drawn in this study are therefore not impacted by using A1B-based SSTs for all simulations.

\section{Results and discussion}

\subsection{Ozone changes resulting from chemistry}

Processes such as stratospheric cooling and the projected strengthening of the Brewer-Dobson circulation, as well as decreasing stratospheric halogen loading are expected to have a large impact on the evolution of stratospheric ozone through the 21st century (Bekki et al., 2011 and references therein). Because we use the same SST and $\mathrm{CO}_{2}$ 


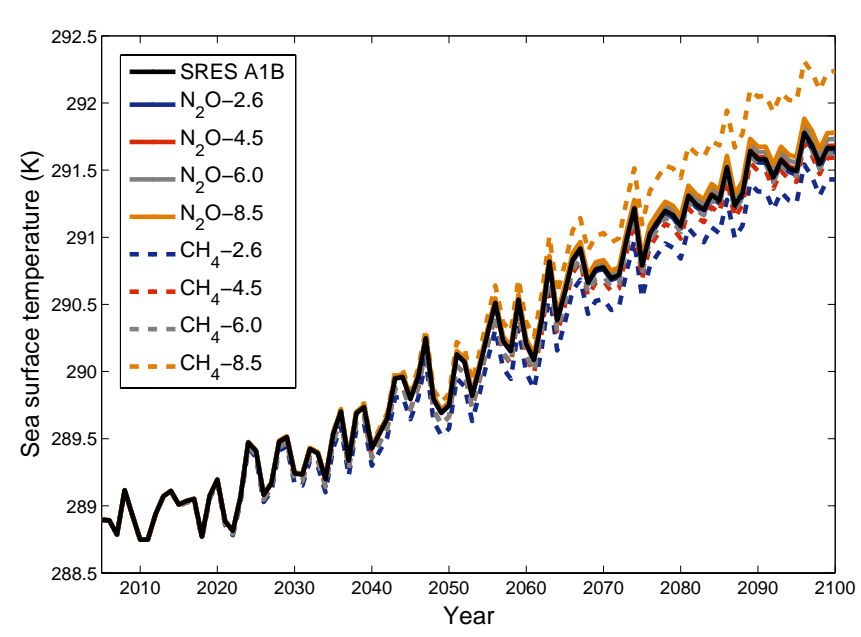

Fig. 2. Global-, annual-mean SSTs. The SRES A1B SSTs were used in all eight CCM simulations. The other SST series were calculated individually for each GHG concentration scenario using MAGICC6.

concentration scenarios for all of our simulations, the effects of stratospheric cooling and the strengthening of the BrewerDobson circulation on ozone (which are driven primarily by $\mathrm{CO}_{2}$ and SST increase, respectively) are the same in all eight simulations. The different $\mathrm{N}_{2} \mathrm{O}$ and $\mathrm{CH}_{4}$ scenarios used allow us to examine the changes in ozone due to these greenhouse gases, which are mostly chemical changes.

In all eight CCM simulations performed for this study, global-mean total column ozone increases through the $21 \mathrm{st}$ century. The magnitude of the increase is listed as $\Delta \mathrm{O}_{3}$ in the rightmost column of Table 1 . In general, this increase is caused by a combination of a slowing of the gas-phase ozone loss cycles due to stratospheric cooling (Rosenfield et al., 2002), and decreasing concentrations of stratospheric chlorine and bromine resulting from the phase-out of halogenated ODSs under the Montreal Protocol (Bekki et al., 2011). The simulations with larger $\mathrm{N}_{2} \mathrm{O}$ surface concentrations lead to a smaller increase in ozone (4.3 DU in $\mathrm{N}_{2} \mathrm{O}-8.5$ compared with 10 DU in $\mathrm{N}_{2} \mathrm{O}-2.6$ ), while those with larger $\mathrm{CH}_{4}$ surface concentrations lead to a larger increase in ozone (16.7 DU in $\mathrm{CH}_{4}-8.5$ compared with 4.4 DU in $\mathrm{CH}_{4}-2.6$ ).

To examine changes in chemically-induced ozone destruction, the differences in the rates of the nitrogen, hydrogen and chlorine cycles in the 2090 s decade between the $\mathrm{N}_{2} \mathrm{O}-8.5$ and $\mathrm{N}_{2} \mathrm{O}-2.6$ simulations $(\mathrm{a}-\mathrm{c})$ and the $\mathrm{CH}_{4}-8.5$ and $\mathrm{CH}_{4}-$ 2.6 simulations $(\mathrm{d}-\mathrm{f})$ are shown in Fig. 3 as a function of pressure and latitude. The ozone-depleting nitrogen cycles speed up with increased $\mathrm{N}_{2} \mathrm{O}$ throughout the upper and middle stratosphere, but remain largely unchanged in the lower stratosphere where concentrations of odd-oxygen are diminished (Fig. 3a). Figure 3b and c show that the hydrogen and chlorine cycles slow down throughout the upper and middle stratosphere through the 21 st century. This is because enhanced ozone depletion due to $\mathrm{NO}_{\mathrm{x}}$ means that the availabil- ity of odd-oxygen to participate in reactions with hydrogen and chlorine species is reduced, as discussed by Revell et al. (2012).

Similarly, Fig. 3e shows that $\mathrm{HO}_{\mathrm{x}}$-induced ozone depletion (mostly due to Cycle I) speeds up with increased $\mathrm{CH}_{4}$ in the upper stratosphere, where the nitrogen and chlorine cycles slow (Fig. 3d and f). $\mathrm{HO}_{\mathrm{x}}$-induced ozone destruction by Cycle II is important in the lower stratosphere, although we do not see the effects of it here as we show the absolute rather than fractional difference between simulations. As well as reduced availability of odd-oxygen, the chlorine cycles slow due to reduced availability of reactive chlorine, as determined by Reaction (R3). Although the effectiveness of Reaction (R3) is diminished in the 2090s decade due to reduced stratospheric chlorine loading, the larger $\mathrm{CH}_{4}$ abundances in simulation $\mathrm{CH}_{4}-8.5$ relative to $\mathrm{CH}_{4}-2.6$ mean that Reaction (R3) is more effective with respect to chlorine deactivation in $\mathrm{CH}_{4}-8.5$.

Differences in $\mathrm{NO}_{\mathrm{x}}$ between the $\mathrm{N}_{2} \mathrm{O}-8.5$ and $\mathrm{N}_{2} \mathrm{O}-2.6$ simulations for the 2090s decade are shown in Fig. 4 as abundances, and calculated as a percentage of $\mathrm{NO}_{\mathrm{x}}$ in the $\mathrm{N}_{2} \mathrm{O}-$ 2.6 simulation. In absolute terms (Fig. 4a), $\mathrm{NO}_{\mathrm{x}}$ species exhibit the greatest increase through the middle stratosphere, whereas the largest fractional increase is observed in the polar stratosphere (Fig. 4b). Similarly, Fig. 4c and d show changes in $\mathrm{H}_{2} \mathrm{O}$ between the $\mathrm{CH}_{4}-8.5$ and $\mathrm{CH}_{4}-2.6$ simulations.

In all eight simulations presented here, ozone increases everywhere except for in the tropical lower stratosphere (not shown). Here, ozone decreases because the enhanced rate of tropical upwelling means there is less time for ozone to form in rising parcels of ozone-poor air from the troposphere to the stratosphere (Avallone and Prather, 1996). In Figs. 5 and 6, we examine the difference between 2090s ozone as a function of latitude and pressure.

Figure 5a shows the difference between 2090s ozone in the $\mathrm{N}_{2} \mathrm{O}-8.5$ and $\mathrm{N}_{2} \mathrm{O}-2.6$ simulations. Ozone is suppressed by as much as $\sim 5-10 \%$ in the middle stratosphere in the $\mathrm{N}_{2} \mathrm{O}$ 8.5 simulation compared to the $\mathrm{N}_{2} \mathrm{O}-2.6$ simulation but is elevated by $\sim 5 \%$ in the tropical lower stratosphere $(\sim 100-$ $70 \mathrm{hPa}$ ). The smaller ozone increase in the $\mathrm{N}_{2} \mathrm{O}-8.5$ simulation is expected and is due to enhanced rates of the ozonedepleting nitrogen cycles (Fig. 3a). The larger ozone abundances in the troposphere and lower stratosphere in the $\mathrm{N}_{2} \mathrm{O}$ 8.5 simulation (relative to the $\mathrm{N}_{2} \mathrm{O}-2.6$ simulation) are likely due to enhanced ozone production by Cycle III, as a result of increased $\mathrm{N}_{2} \mathrm{O}$ and therefore $\mathrm{NO}_{\mathrm{x}}$ abundances. This was also observed by Portmann and Solomon (2007), who studied the effects of $\mathrm{N}_{2} \mathrm{O}$ on ozone.

The difference between 2090s total column ozone in the $\mathrm{N}_{2} \mathrm{O}-8.5$ and $\mathrm{N}_{2} \mathrm{O}-2.6$ simulations is shown in Fig. 5b as a function of latitude. Because the middle stratosphere dominates the ozone column, total column ozone is suppressed at all latitudes in the $\mathrm{N}_{2} \mathrm{O}-8.5$ simulation relative to the $\mathrm{N}_{2} \mathrm{O}$ 2.6 simulation (but less so in the tropical stratosphere). The 
(a)

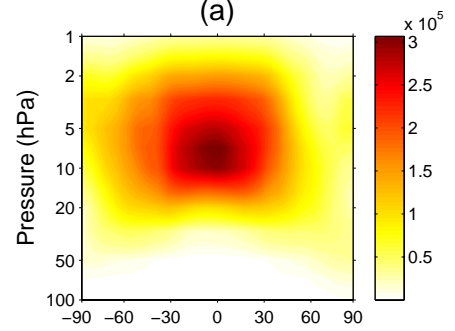

(d)

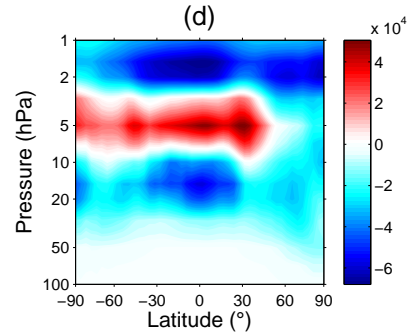

(b)

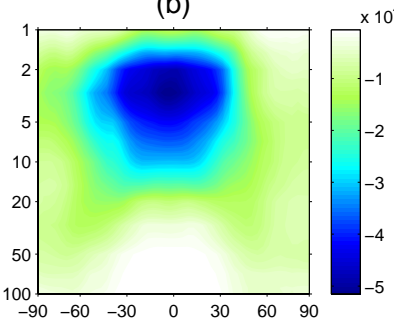

(e)

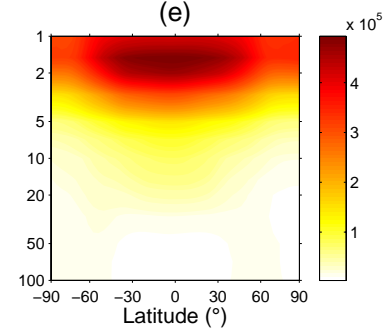

(c)

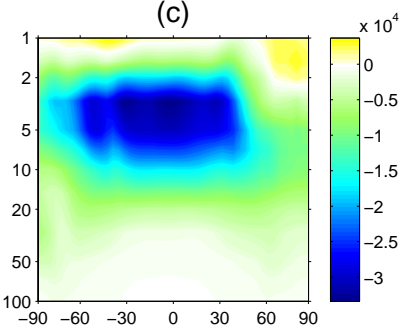

(f)

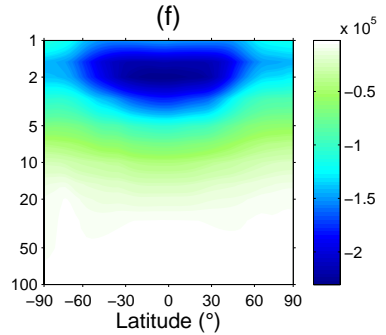

Fig. 3. (a) Contribution to ozone loss (molecules $\mathrm{cm}^{-3} \mathrm{~s}^{-1}$ ) from the nitrogen cycles as a function of pressure and latitude in the 2090s decade in the $\mathrm{N}_{2} \mathrm{O}-8.5$ simulation, minus the same quantity for the $\mathrm{N}_{2} \mathrm{O}-2.6$ simulation. (b) Same as (a), but for the hydrogen cycles. (c) Same as (a), but for the chlorine cycles. (d) Contribution to ozone loss from the nitrogen cycles as a function of pressure and latitude in the 2090s decade in the $\mathrm{CH}_{4}-8.5$ simulation, minus the same quantity for the $\mathrm{CH}_{4}-2.6$ simulation. (e) Same as (d), but for the hydrogen cycles. (f) Same as (d), but for the chlorine cycles. Note the different orders of magnitude on the colour scales.

(a)

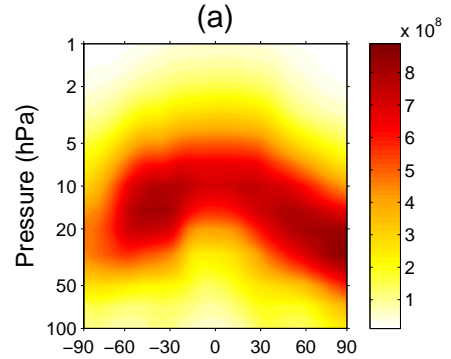

(c)

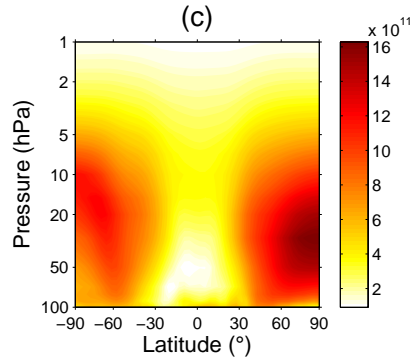

(b)

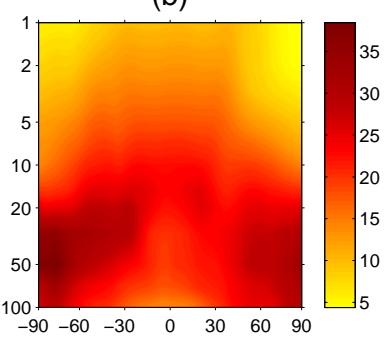

(d)

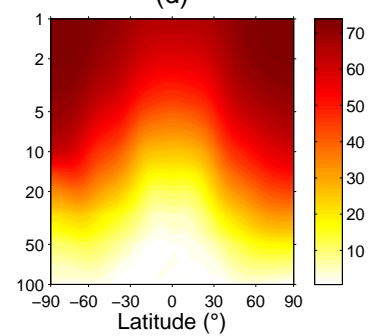

Fig. 4. (a) $\mathrm{NO}_{\mathrm{x}}$ abundance (molecules $\mathrm{cm}^{-3}$ ) in the 2090s decade for the $\mathrm{N}_{2} \mathrm{O}-8.5$ simulation, minus the same quantity for the $\mathrm{N}_{2} \mathrm{O}$ 2.6 simulation. (b) The quantity in (a) expressed as a percentage of 2090s $\mathrm{NO}_{\mathrm{x}}$ abundance for the $\mathrm{N}_{2} \mathrm{O}-2.6$ simulation. (c) Abundance of water vapour (molecules $\mathrm{cm}^{-3}$ ) in the 2090 s decade for the $\mathrm{CH}_{4}$ 8.5 simulation, minus the same quantity for the $\mathrm{CH}_{4}-2.6$ simulation. (d) The quantity in (c) expressed as a percentage of 2090s water vapour abundance for the $\mathrm{CH}_{4}-2.6$ simulation.

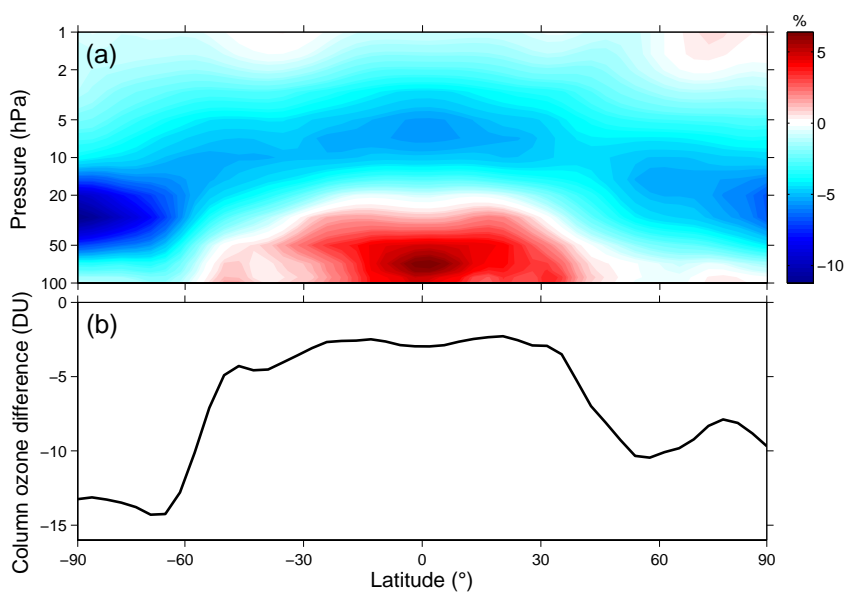

Fig. 5. (a) $\mathrm{N}_{2} \mathrm{O}-8.5$ ozone minus $\mathrm{N}_{2} \mathrm{O}-2.6$ ozone in the $2090 \mathrm{~s}$ decade, calculated as a percentage of ozone in the $\mathrm{N}_{2} \mathrm{O}-2.6$ simulation. (b) 2090s-decade $\mathrm{N}_{2} \mathrm{O}-8.5$ total column ozone minus $\mathrm{N}_{2} \mathrm{O}-2.6$ total column ozone.

largest ozone decrease is seen at $50 \mathrm{hPa}$ in the Antarctic stratosphere, which could be due to the large increase in $\mathrm{NO}_{\mathrm{x}}$ in this region (Fig. $4 \mathrm{~b}$ ).

Figure 6 is similar to Fig. 5, but shows the differences between simulations $\mathrm{CH}_{4}-8.5$ and $\mathrm{CH}_{4}-2$.6. In simulation $\mathrm{CH}_{4}$ 8.5 , ozone increases of up to $\sim 15 \%$ greater than those in the $\mathrm{CH}_{4}-2.6$ simulation are seen throughout the stratosphere, except for in the upper stratosphere where ozone is suppressed by more than $5 \%$ due to enhanced rates of the $\mathrm{HO}_{\mathrm{x}}$ ozone loss cycles. Through the middle stratosphere, the rate 


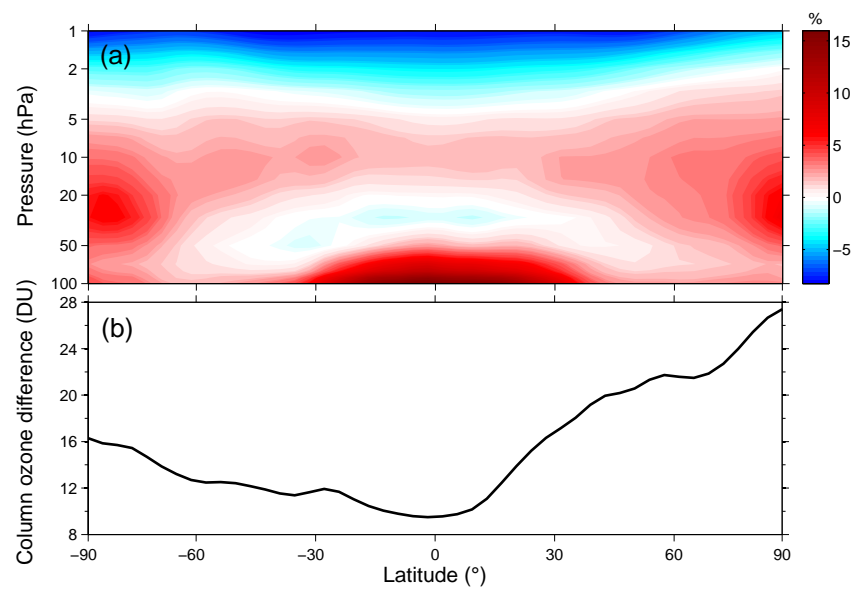

Fig. 6. (a) $\mathrm{CH}_{4}-8.5$ ozone minus $\mathrm{CH}_{4}-2.6$ ozone in the $2090 \mathrm{~s}$ decade, calculated as a percentage of ozone in the $\mathrm{CH}_{4}-2.6$ simulation. (b) 2090 s-decade $\mathrm{CH}_{4}-8.5$ total column ozone minus $\mathrm{CH}_{4}-2.6$ total column ozone.

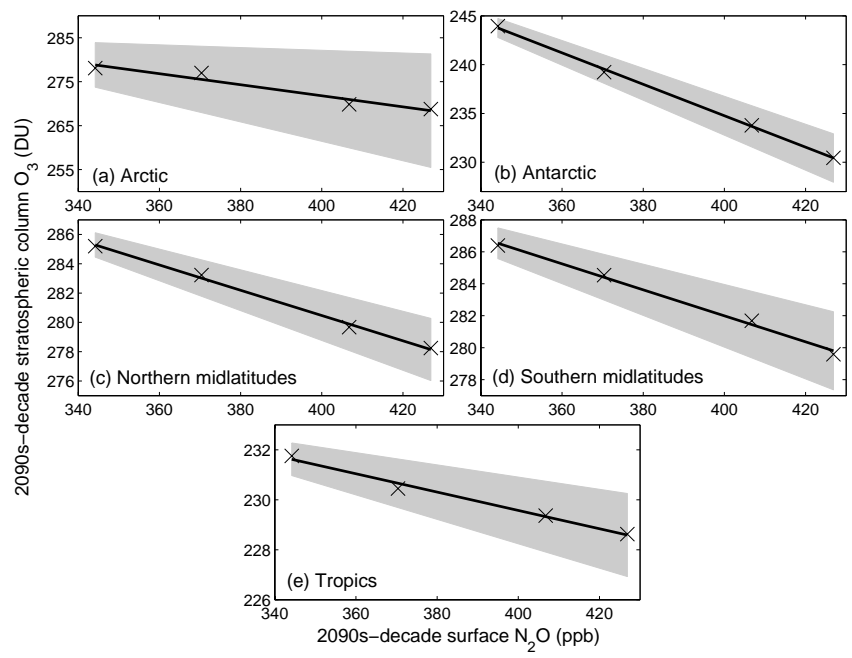

Fig. 7. (a) $2090 \mathrm{~s}-\mathrm{mean}$ Arctic $\left(63-90^{\circ} \mathrm{N}\right)$ stratospheric column ozone (1-100 hPa) vs. 2090s-mean surface $\mathrm{N}_{2} \mathrm{O}$ for the four $\mathrm{N}_{2} \mathrm{O}$ simulations (crosses), fitted with a simple linear regression model (black line). The grey shaded region indicates the $95 \%$ confidence interval for the slope and intercept of the regression model. (be) As for (a), but for: (b) the Antarctic $\left(63-90^{\circ} \mathrm{S}\right)$; (c) northern midlatitudes $\left(30-60^{\circ} \mathrm{N}\right)$; (d) southern midlatitudes $\left(30-60^{\circ} \mathrm{S}\right)$; (e) the tropics $\left(25^{\circ} \mathrm{N}-25^{\circ} \mathrm{S}\right)$.

of Reaction (R3) increases in simulation $\mathrm{CH}_{4} 8.5$ relative to $\mathrm{CH}_{4}-2.6$, thus decreasing the abundance of reactive chlorine and slowing the chlorine cycles (Fig. 3f). Additionally, increasing $\mathrm{CH}_{4}$ leads to an increase in $\mathrm{H}_{2} \mathrm{O}$ (Fig. $4 \mathrm{c}$ and d), which in turn cools the stratosphere and slows ozone depletion. $\mathrm{H}_{2} \mathrm{O}$ increases noticeably in the Arctic polar stratosphere (Fig. 4c), where subsequent cooling could explain the relatively large ozone increase observed in Fig. 6b. This is in contrast to the findings of Kirk-Davidoff et al. (1999), Feck

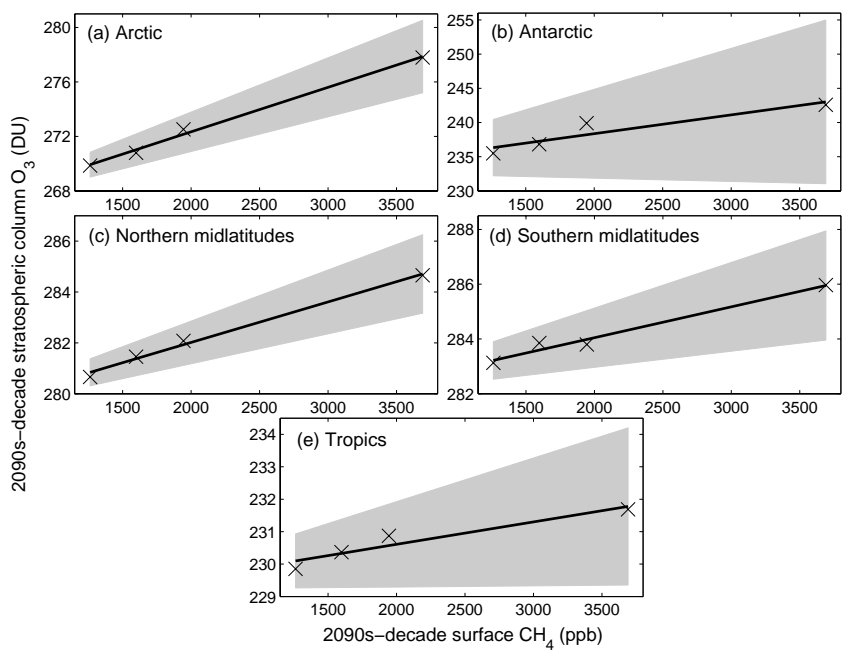

Fig. 8. Similar to Fig. 7, but for 2090s-mean stratospheric column ozone vs. 2090s-mean surface $\mathrm{CH}_{4}$ for the four $\mathrm{CH}_{4}$ simulations.

et al. (2008) and Vogel et al. (2011), who found that cooler temperatures resulting from increases in water vapour lead to enhanced heterogeneous chlorine chemistry and subsequent ozone loss. It is likely that because we focus on the 2090s decade in our analysis, when stratospheric chlorine levels are very low, heterogeneous chemistry is no longer of significance to polar ozone depletion.

$\mathrm{CH}_{4}$ increases lead to an increase in $\mathrm{HO}_{\mathrm{x}}$ abundances, which drive the rate of Cycle III. Therefore, in the troposphere and lower stratosphere, the relative increase in ozone between simulations $\mathrm{CH}_{4}-8.5$ and $\mathrm{CH}_{4}-2.6$ is likely due to enhanced ozone production by Cycle III. This mechanism was put forward by Portmann and Solomon (2007) and Fleming et al. (2011) to explain tropospheric and lower stratospheric ozone increases observed in simulations designed to isolate the impact of $\mathrm{CH}_{4}$ on ozone. It should be noted that NIWA-SOCOL does not include oxidation of nonmethane hydrocarbons in its tropospheric chemistry mechanism; therefore, ozone production by Cycle III is underestimated in the model simulations presented here.

\subsection{The sensitivity of ozone to $\mathrm{N}_{2} \mathrm{O}$ and $\mathrm{CH}_{4}$}

To test whether there is a linear relationship between stratospheric ozone at the end of the 21st century, and the $\mathrm{N}_{2} \mathrm{O}$ or $\mathrm{CH}_{4}$ concentration at that time, linear fits to 2090s-mean stratospheric ozone columns $(1-100 \mathrm{hPa})$ as a function of $\mathrm{N}_{2} \mathrm{O}$ or $\mathrm{CH}_{4}$ concentrations were calculated in five regions of the stratosphere (Figs. 7 and 8). The slopes for the linear fits in Figs. 7 and 8 are given in Table 2, along with the $\mathrm{R}^{2}$-values. The shaded regions in Figs. 7 and 8 represent the $95 \%$ confidence interval calculated for the slope and intercept of the linear regression models.

As shown in Fig. 7 and Table 2, the slopes for the linear fits are negative in all regions of the stratosphere, and the 
Table 2. Linear regression model slopes and $\mathrm{R}^{2}$-values.

\begin{tabular}{|c|c|c|c|c|}
\hline & \multicolumn{2}{|c|}{$\mathrm{N}_{2} \mathrm{O}$ simulations } & \multicolumn{2}{|c|}{$\mathrm{CH}_{4}$ simulations } \\
\hline & Slope (DU ppb $\left.{ }^{-1}\right)$ & $\mathrm{R}^{2}$-value & Slope (DU ppb $\left.{ }^{-1}\right)$ & $\mathrm{R}^{2}$-value \\
\hline $\operatorname{Arctic}\left(63-90^{\circ} \mathrm{N}\right)$ & -10.4 & 0.942 & 7.9 & 0.995 \\
\hline Northern midlatitudes $\left(30-60^{\circ} \mathrm{N}\right)$ & -7.1 & 0.996 & 3.9 & 0.993 \\
\hline Tropics $\left(25^{\circ} \mathrm{N}-25^{\circ} \mathrm{S}\right)$ & -3 & 0.988 & 1.7 & 0.912 \\
\hline Southern midlatitudes $\left(30-60^{\circ} \mathrm{S}\right)$ & -6.7 & 0.995 & 2.7 & 0.976 \\
\hline Antarctic $\left(63-90^{\circ} \mathrm{S}\right)$ & -13.3 & 0.999 & 6.7 & 0.870 \\
\hline
\end{tabular}

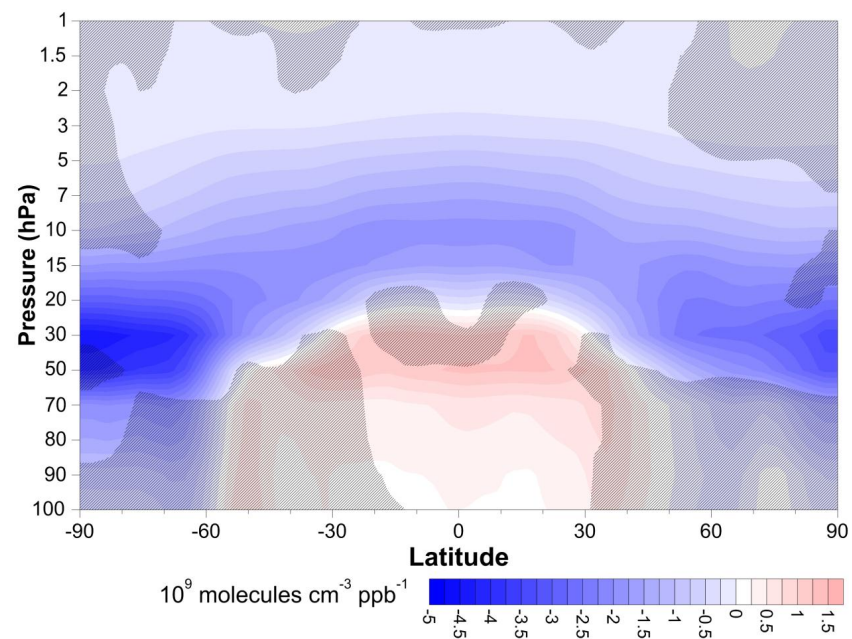

Fig. 9. Slopes from simple linear regression models fitted to 2090smean ozone vs. 2090s-mean surface $\mathrm{N}_{2} \mathrm{O}$ for all latitudes and all pressure levels between $1-100 \mathrm{hPa}$, for the four $\mathrm{N}_{2} \mathrm{O}$ simulations. Hatching indicates that the slope was not statistically significantly different from zero at the $95 \%$ level of confidence.

$\mathrm{R}^{2}$-values exceed 0.94 everywhere. All fits are statistically significantly different from zero at the $95 \%$ confidence level, indicating a strong linear relationship between stratospheric ozone abundance and $\mathrm{N}_{2} \mathrm{O}$ concentrations. The linear fits between ozone and $\mathrm{CH}_{4}$ in Fig. 8 all have positive slopes, and are statistically significantly different from zero at the $95 \%$ confidence level in all regions of the stratosphere except for the Antarctic, where the $\mathrm{R}^{2}$-value is 0.87. Elsewhere, the $\mathrm{R}^{2}$ value exceeds 0.91 . For both the $\mathrm{N}_{2} \mathrm{O}$ and $\mathrm{CH}_{4}$ simulations, sensitivities in the polar regions are enhanced compared with the tropics and midlatitudes. For the $\mathrm{N}_{2} \mathrm{O}$ simulations, this is likely due to the change in $\mathrm{NO}_{\mathrm{x}}$ loading, which shows the greatest relative increase in the polar stratosphere (Fig. 4b). For the $\mathrm{CH}_{4}$ simulations, the likely cause is the large increase in water vapour observed in the polar regions (Fig. 4c), as discussed earlier.

Figures 9 and 10 show the slopes of linear fits to 2090sozone vs. $\mathrm{N}_{2} \mathrm{O}$ or $\mathrm{CH}_{4}$ surface concentrations as a function of pressure and latitude. Regions where the slope is not statistically significantly different from zero at the $95 \%$ con-

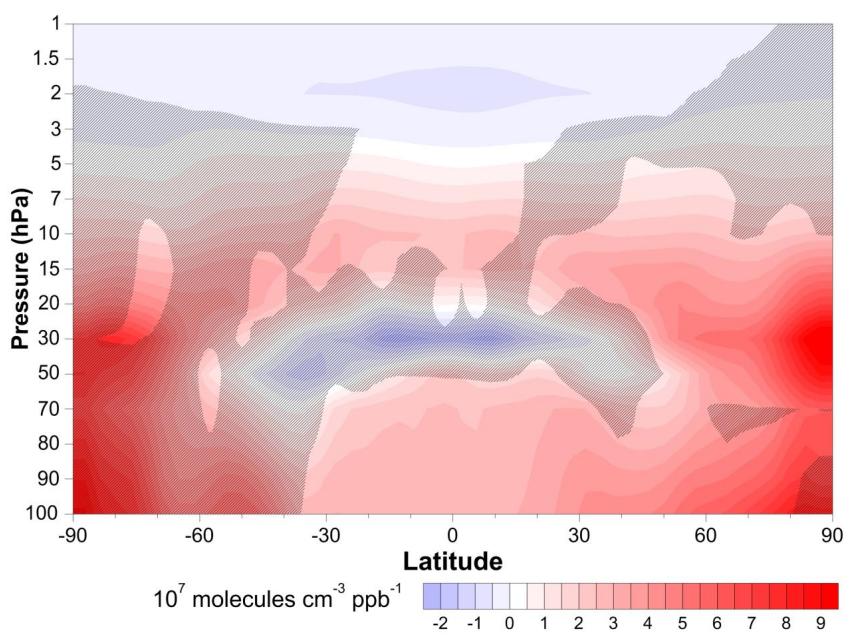

Fig. 10. Similar to Fig. 9, but the slopes are from simple linear regression models fitted to 2090s-mean ozone vs. 2090s-mean surface $\mathrm{CH}_{4}$ for the four $\mathrm{CH}_{4}$ simulations.

fidence bounds are hatched. Figure 9 shows that in the polar regions, and throughout most of the middle stratosphere, ozone demonstrates a statistically significant negative linear relationship with $\mathrm{N}_{2} \mathrm{O}$. There is a positive correlation in the tropical lower stratosphere, where enhanced $\mathrm{N}_{2} \mathrm{O}$ leads to ozone production. Figure 10 shows that ozone decreases linearly with increasing $\mathrm{CH}_{4}$ in the upper stratosphere, and that this relationship is statistically significant at the $95 \%$ confidence level. Statistically significant relationships between ozone and $\mathrm{CH}_{4}$ are also found, for example, through much of the tropical, northern-midlatitude and Arctic stratosphere, where ozone increases with increasing $\mathrm{CH}_{4}$.

These quasi-linear relationships between ozone and $\mathrm{N}_{2} \mathrm{O}$ and $\mathrm{CH}_{4}$ over the range of RCP scenarios tested here suggest that perturbations to either stratospheric column ozone (using the results presented in Figs. 7 and 8) or to vertically resolved ozone (using the results presented in Figs. 9 and 10) can be incorporated into simple models of stratospheric ozone to capture the changes in ozone resulting from changes in $\mathrm{N}_{2} \mathrm{O}$ and $\mathrm{CH}_{4}$ (noting that such parameterizations do not require a strict one way causality between $\mathrm{N}_{2} \mathrm{O}$ and $\mathrm{CH}_{4}$ changes and total column ozone response). However, the fits are based on 
only four points and a single $\mathrm{CO}_{2}$ and $\mathrm{CH}_{4}$ scenario for the $\mathrm{N}_{2} \mathrm{O}$ simulations and a single $\mathrm{CO}_{2}$ and $\mathrm{N}_{2} \mathrm{O}$ scenario for the $\mathrm{CH}_{4}$ simulations; ozone may not exhibit this apparent linear sensitivity under different greenhouse gas scenarios.

\section{Conclusions}

Total column ozone increases through the 21st century in all of the eight CCM simulations presented here, due to decreased stratospheric chlorine loading and $\mathrm{CO}_{2}$-induced cooling of the stratosphere. Larger increases are observed in simulations with low $\mathrm{N}_{2} \mathrm{O}$ or high $\mathrm{CH}_{4}$ concentrations. $\mathrm{N}_{2} \mathrm{O}$ decreases stratospheric ozone abundance by increasing the rate of the ozone-depleting nitrogen cycles. Although mid- and lower-stratospheric ozone increase in response to increased $\mathrm{CH}_{4}$, upper stratospheric ozone decreases due to an increase in the rate of the ozone-depleting hydrogen cycles. Furthermore, we have shown that at the end of the 21 st century, stratospheric column ozone decreases linearly with increasing surface $\mathrm{N}_{2} \mathrm{O}$ concentrations in all regions of the stratosphere. In contrast, stratospheric column ozone increases linearly with increasing $\mathrm{CH}_{4}$ concentrations, however this relationship is not statistically significant at the $95 \%$ confidence level in the Antarctic stratosphere. We have also shown the vertically-resolved relationship between ozone and $\mathrm{N}_{2} \mathrm{O}$ and $\mathrm{CH}_{4}$; ozone demonstrates a statistically significant negative linear relationship with $\mathrm{N}_{2} \mathrm{O}$ in the polar and middle stratosphere, and with $\mathrm{CH}_{4}$ in the upper stratosphere. Ozone increases are positively correlated with $\mathrm{CH}_{4}$ increases in the middle and lower stratosphere, although this increase is not statistically significant at the $95 \%$ confidence level through much of the southern midlatitude and polar stratosphere. Our conclusions are derived from simulations based on a single $\mathrm{CO}_{2}$ concentration scenario, and ozone may not exhibit this linear sensitivity under different $\mathrm{CO}_{2}$ scenarios; this will be the subject of future work.

Acknowledgements. We would like to thank Dan Smale for his help in running the NIWA-SOCOL simulations, and Malte Meinshausen for providing us with the MAGICC6 model.

Edited by: M. Dameris

\section{References}

Avallone, L. M. and Prather, M. J.: Photochemical evolution of ozone in the lower tropical stratosphere, J. Geophys. Res., 101, 1457-1461, 1996.

Bekki, S., Bodeker, G. E. (Coordinating Lead Authors), Bais, A. F., Butchart, N., Eyring, V., Fahey, D. W., Kinnison, D. E., Langematz, U., Mayer, B., Portmann, R. W., Rozanov, E., Braesicke, P., Charlton-Perez, A. J., Chubarova, N. E., Cionni, I., Diaz, S. B., Gillett, N. P., Giorgetta, M. A., Komala, N., Lefèvre, F., McLandress, C., Perlwitz, J., Peter, T., and Shibata, K.: Future ozone and its impact on surface UV, Chapter 3, in: Scientific Assessment of Ozone Depletion: 2010, Global Ozone Research and Monitoring Project - Report No. 52, 516 pp., World Meteorological Organization, Geneva, Switzerland, 2011.

Cook, P. A. and Roscoe, H. K.: Changes in reactive stratospheric gases due to a change in Brewer-Dobson circulation: results from a simple model, Atmos. Sci. Lett., 13, 49-54, 2012.

Crutzen, P. J.: The influence of nitrogen oxides on the atmospheric ozone content, Q. J. Roy. Meteor. Soc., 96, 320-325, 1970.

Daniel, J. S., Velders, G. J. M. (Lead Authors), Douglass, A. R., Forster, P. M. D., Hauglustaine, D. A., Isaksen, I. S. A., Kuijpers, L. J. M., McCulloch, A. and Wallington, T. J.: Halocarbon scenarios, ozone depletion potentials, and global warming potentials, Chapter 8, in: Scientific Assessment of Ozone Depletion: 2006, Global Ozone Research and Monitoring Project - Report No. 50, 572 pp., World Meteorological Organization, Geneva, Switzerland, 2007.

Douglass, A. R., Schoeberl, M. R., Stolarski, R. S., Waters, J. W., Russell III, J. M., Roche, A. E., and Massie, S. T.: Interhemispheric differences in springtime production of $\mathrm{HCl}$ and $\mathrm{ClONO}_{2}$ in the polar vortices, J. Geophys. Res., 100, 13967-13978, 1995.

Egorova, T. A., Rozanov, E. V., Zubov, V. A., and Karol, I. L.: Model for investigating ozone trends (MEZON), Izv. Atmos. Ocean. Phys., 39, 277-292, 2003.

Eyring, V., Cionni, I., Bodeker, G. E., Charlton-Perez, A. J., Kinnison, D. E., Scinocca, J. F., Waugh, D. W., Akiyoshi, H., Bekki, S., Chipperfield, M. P., Dameris, M., Dhomse, S., Frith, S. M., Garny, H., Gettelman, A., Kubin, A., Langematz, U., Mancini, E., Marchand, M., Nakamura, T., Oman, L. D., Pawson, S., Pitari, G., Plummer, D. A., Rozanov, E., Shepherd, T. G., Shibata, K., Tian, W., Braesicke, P., Hardiman, S. C., Lamarque, J. F., Morgenstern, O., Pyle, J. A., Smale, D., and Yamashita, Y.: Multimodel assessment of stratospheric ozone return dates and ozone recovery in CCMVal-2 models, Atmos. Chem. Phys., 10, 94519472, doi:10.5194/acp-10-9451-2010, 2010.

Feck, T., Grooß, J.-U. And Riese, M.: Sensitivity of Arctic ozone loss to stratospheric $\mathrm{H}_{2} \mathrm{O}$, Geophys. Res. Lett., 35, L01803, doi:10.1029/2007GL031334, 2008.

Fleming, E. L., Jackman, C. H., Stolarski, R. S., and Douglass, A. R.: A model study of the impact of source gas changes on the stratosphere for 1850-2100, Atmos. Chem. Phys., 11, 85158541, doi:10.5194/acp-11-8515-2011, 2011.

IPCC/TEAP; Metz, B., Kuijpers, L., Solomon, S., Andersen, S. O., Davidson, O., Pons, J., de Jager, D., Kestin, T., Manning, M., and Meyer, L.: Safeguarding the Ozone Layer and the Global Climate System: Issues related to hydrofluorocarbons and perfluorocarbons, Cambridge University Press, UK, Geneva, 2005.

Johnston, H. S. and Podolske, J.: Interpretations of stratospheric photochemistry, Rev. Geophys. Space Phys., 16, 491-519, 1978.

Kirk-Davidoff, D. B., Hintsa, E. J., Anderson, J. G., and Keith, D. W.: The effect of climate change on ozone depletion through changes in stratospheric water vapour, Nature, 402, 399-401, doi:10.1038/46521, 1999.

Lee, A. M., Jones, R. L., Kilbane-Dawe, I., and Pyle, J. A.: Diagnosing ozone loss in the extratropical lower stratosphere, J. Geophys. Res., 107, 4110, doi:10.1029/2001JD000538, 2002.

Manzini, E., McFarlane, N. A., and McLandress, C.: Impact of the Doppler spread parameterization on the simulation of the middle atmosphere circulation using the MA/ECHAM4 general 
circulation model, J. Geophys. Res., 102, 25751-25762, 1997.

Meinshausen, M., Raper, S. C. B., and Wigley, T. M. L.: Emulating coupled atmosphere-ocean and carbon cycle models with a simpler model, MAGICC6 - Part 1: Model description and calibration, Atmos. Chem. Phys., 11, 1417-1456, doi:10.5194/acp11-1417-2011, 2011.

Nakicenovic, N. and Swart, R. (Eds.): IPCC Special Report on Emissions Scenarios, Cambridge Univ. Press, Cambridge, UK, 2000

Nevison, C. D., Solomon, S., and Gao, R. S.: Buffering interactions in the modeled response of stratospheric $\mathrm{O}_{3}$ to increased $\mathrm{NO}_{\mathrm{x}}$ and $\mathrm{HO}_{\mathrm{x}}$, J. Geophys. Res., 104, 3741-3754, 1999.

Oman, L. D., Waugh, D. W., Kawa, S. R., Stolarski, R. S., Douglass, A. R., and Newman, P. A.: Mechanisms and feedback causing changes in upper stratospheric ozone in the 21 st century, J. Geophys. Res., 115, D05303, doi:10.1029/2009JD012397, 2010.

Plummer, D. A., Scinocca, J. F., Shepherd, T. G., Reader, M. C., and Jonsson, A. I.: Quantifying the contributions to stratospheric ozone changes from ozone depleting substances and greenhouse gases, Atmos. Chem. Phys., 10, 8803-8820, doi:10.5194/acp-108803-2010, 2010.

Portmann, R. W. and Solomon, S.: Indirect radiative forcing of the ozone layer during the 21 st century, Geophys. Res. Lett., 34, L02813, doi:10.1029/2006GL028252, 2007.

Randeniya, L. K., Vohralik, P. F., and Plumb, I. C.: Stratospheric ozone depletion at northern mid latitudes in the 21st century: The importance of future concentrations of greenhouse gases nitrous oxide and methane, Geophys. Res. Lett., 29, 41051, doi:10.1029/2001GL014295, 2002.

Ravishankara, A. R., Daniel, J. S., and Portmann, R. W.: Nitrous oxide $\left(\mathrm{N}_{2} \mathrm{O}\right)$ : The dominant ozone-depleting substance emitted in the 21st century, Science, 326, 123-125, doi:10.1126/science.1176985, 2009.

Revell, L. E., Bodeker, G. E., Smale, D., Lehmann, R., Huck, P. E., Williamson, B. E., Rozanov, E. and Struthers, H.: The effectiveness of $\mathrm{N}_{2} \mathrm{O}$ in depleting stratospheric ozone, Geophys. Res. Lett., 39, L15806, doi:10.1029/2012GL052143, 2012.
Rosenfield, J. E. and Douglass, A. R.: Doubled $\mathrm{CO}_{2}$ effects on $\mathrm{NO}_{\mathrm{y}}$ in a coupled 2D model, Geophys. Res. Lett., 25, 4381-4384, 1998.

Rosenfield, J. E., Douglass, A. R., and Considine, D. B.: The impact of increasing carbon dioxide on ozone recovery, J. Geophys. Res., 107, 4049, doi:10.1029/2001JD000824, 2002.

Schraner, M., Rozanov, E., Schnadt Poberaj, C., Kenzelmann, P., Fischer, A. M., Zubov, V., Luo, B. P., Hoyle, C. R., Egorova, T., Fueglistaler, S., Brönnimann, S., Schmutz, W., and Peter, T.: Technical Note: Chemistry-climate model SOCOL: version 2.0 with improved transport and chemistry/microphysics schemes, Atmos. Chem. Phys., 8, 5957-5974, doi:10.5194/acp-8-59572008, 2008.

SPARC CCMVal: SPARC Report on the Evaluation of Chemistry-Climate Models, edited by: Eyring, V., Shepherd, T. G., and Waugh, D. W., SPARC Report No. 5, WCRP-132, WMO/TD-No. 1526, http://www.sparc-climate. org/publications/sparc-reports/sparc-report-no5/, 2010.

van Vuuren, D. P., Edmonds, J., Kainuma, M., Riahi, K., Thomson, A., Hibbard, K., Hurtt, G. C., Kram, T., Krey, V., Lamarque, J. F., Masui, T., Meinshausen, M., Nakicenovic, N., Smith, S. J., and Rose, S. K.: The representative concentration pathways: an overview, Climatic Change, 109, 5-31, doi:10.1007/s10584-0110148-z, 2011.

Vogel, B., Feck, T., and Grooß, J.-U.: Impact of stratospheric water vapour enhancements caused by $\mathrm{CH}_{4}$ and $\mathrm{H}_{2} \mathrm{O}$ increase on polar ozone loss, J. Geophys. Res., 116, D05301, doi:10.1029/2010JD014234, 2011.

World Meteorological Organization: Scientific Assessment of Ozone Depletion: 1998, WMO Global Ozone Research and Monitoring Project - Report No. 44, Geneva, 1998.

Zubov, V., Rozanov, E., and Schlesinger, M.: Hybrid scheme for three-dimensional advective transport, Mon. Weather Rev., 127, 1335-1346, 1999. 